DOI: https://doi.org/10.18371/fp.3(43).2021.100112

УДК 347.781 .51

\title{
ВВЕДЕННЯ У ГОСПОДАРСЬКИЙ ОБІГ ВЕБСАЙТІВ: ПРОБЛЕМИ ІДЕНТИФІКАЦІЇ ТА ОБЛІКОВОГО ВІДОБРАЖЕННЯ
}

\author{
ГОЙ Василь Васильович \\ кандидат економічних наук, \\ директор Інституту оцінки та судових експертиз \\ ORCID ID: https://orcid.org/0000-0003-1822-4478
}

\begin{abstract}
Анотація. Стаття присвячена висвітленню такої актуальної теми, як тлумачення поняття вебсайту, визначення його правового режиму, ідентифікаиії та облікового відображення. Виявлено, щзо вебсайт як об'єкт інтелектуальної власності є складним явищем, яке містить у собі елементи різних правових понять права інтелектуальної власності. Обгрунтовано, щзо правова природа вебсайту має комплексний характер з огляду на його технічну складову частину, графічне й інформаційне оформлення. Доведено існування двох способів ідентифікаиії вебсайтів - символьний у вигляді доменного імені й чисельний, а також важливість облікового запису для ідентифікації користувача в мережі Інтернет. Окреслено, щчо подальші дослідження повинні бути спрямовані на використання методологічних підходів та методів оцінки інтелектуальної власності для визначення вартості вебсайту, як складного об'єкта інтелектуальної власності, а також рекомендацій щзодо захисту прав на вебсайт на законодавчому рівні.
\end{abstract}

Ключові слова: Інтернет, вебсайт, доменне ім'я, обліковий запис, ідентифікація, сервер.

Постановка проблеми. Одне iз центральних місць у сучасному праві посідає проблема важливості визна-
Аннотация. Статья посвящена актуальной теме толкование понятия вебсайта, определение его правового режима, идентификачии и учетного отражения. Выявлено, что вебсайт, как объект интеллектуальной собственности, является сложным явлением, которое включает в себя элементь различных правовых понятий права интеллектуальной собственности. Обосновано, что правовая природа вебсайта имеет комплексныи характер, учитывая его техническую составляюшую, графическое и информаичинное оформление. Доказано существование двух способов идентификачии вебсайтов - символьный в виде доменного имени и численный, а также важность учетной записи для идентификации пользователя в сети Интернет. Определено, что дальнейшие исследования должны быть направлены на использование методологических подходов и методов оченки интеллектуальной собственности для определения стоимости вебсайта, как сложного объекта интеллектуальной собственности, а также рекомендащий по защите прав на вебсайт на законодательном уровне.

Ключевые слова: Интернет, веб-сайт, доменное имя, аккаунт, идентификация, сервер.

чення правового режиму вебсайту. Розбіжності щодо визначення як самого поняття «вебсайт», так і особливості 
його правового регулювання створили певні суперечливості в процесі аналізу розуміння правовідносин, які виникають у зв'язку із користуванням вебсайтів. Тому висвітлення всіх аспектів цього феномена має сприяти вдосконаленню всіх положень як IT права, так і сфери права інтелектуальної власності, враховуючи, що вебсайт $\epsilon$ складним і комплексним за структурою, окремим і самостійним об'єктом правових, інформаційних та економічних відносин.

Аналіз останніх досліджень та публікацій. Зусилля сучасних правознавців спрямовані на розгляд проблем визначення поняття вебсайту та його правового режиму. Позиція дослідження вебсайту та його складників, як об'єктів права інтелектуальної власності, висвітлено в наукових працях таких учених, як Ю. Атаманової [1], С. Булат [2], I. Губіна [3], Т. Деркач [4], Т. Михайліної [5] та ін.

Проте, треба зазначити, що на сьогодні правове поле регулювання функціонування вебсайтів тільки формується, що, в свою чергу, потребує подальших досліджень.

Метою статті $\epsilon$ узагальнення теоретичних та практичних аспектів правового режиму, ідентифікації та облікового відображення вебсайту.

Досягнення мети передбачає вирішення таких науково-дослідних завдань:

- розглянути теоретичні та практичні аспектів питання правового режиму, ідентифікації та облікового відображення вебсайту;

- проаналізувати чинне законодавство щодо цього аспекту.

Виклад основного матеріалу дослідження. На сьогодні користування мережею Інтернет у Світовому Спів- товаристві сприймається не тільки як комфортне та віддалене використання різного роду інформативного масиву, соціального спілкування тощо, а й як особливе користування певними інтелектуальними благами людства.

Всесвітня павутина, тобто WorldWibe Web, - система доступів до взаємопов'язаних гіпертекстових документів через Інтернет. Під поняттям «Інтернет» слід розуміти систему, завдяки якій здійснюється передача даних, а під поняттям «Веб» слід розуміти самі дані. Інтернет - це лише один iз способів отримання даних, що поширюється через Інтернет. Тож Інтернет - це не веб, і ці два терміни не варто плутати або використовувати як взаємозамінні [6].

Від самого початку веб-сайти були класифіковані за їх доменами верхнього рівня [7], наприклад:

- вебсайти державних установ = .gov

- вебсайти навчальних закладів = .edu

- вебсайти некомерційних організацій $=$.org

- комерційні вебсайти $=. c o m$

- інформаційні сайти $=$.info

Поняття вебсайту визначено в Україні на законодавчому рівні. Згідно Закону України «Про авторське право та суміжні права» встановлено, що вебсайт - це сукупність даних, електронної (цифрової) інформації, інших об'єктів авторського права і (або) суміжних прав тощо, пов'язаних між собою і структурованих у межах адреси вебсайту i (або) облікового запису власника цього вебсайту, доступ до яких здійснюється через адресу мережі Інтернет, що може складатися 3 доменного імені, записів про каталоги або виклики і (або) числової адреси за 
Інтернет-протоколом [8]. 3 цього визначення можна дійти висновку, що поняття вебсайту варто розглядати через призму галузі права інтелектуальної власності, оскільки вказана дефініція пов'язана передусім з багатьма об'єктами такого права.

Варто зазначити, що на науковому рівні це поняття неодноразово висвітлювали вчені в наукових публікаціях, зокрема, на думку О.С. Яворської вебсайт - це доволі складний об’єкт інтелектуального права, так як має програмні засоби, інформаційне наповнення (зображення, тексти, тощо) та унікальне ім'я (доменне ім'я). Інформація, яка міститься на вебсайтах, зберігається на віддаленому комп'ютері ( це процес характеризується як хостинг), а також що доступ до інтернет-сайту можливий 3 будь-якого комп'ютера, що підключений до мережі Інтернет, завдяки використанню відповідного програмного забезпечення [9, с. 33]. Такий підхід дозволяє зробити висновок про те, що таке явище як вебсайт містить в собі наступні об'єкти права інтелектуальної власності: авторські тексти, графічні зображення, музичні твори тощо. Відповідно до цього слід розуміти про наявність певного правового режиму такого явища, як вебсайт. Виражається правовий режим передусім у системі діючого законодавства, сукупності методів правового регулювання, процесах правотворчості і реалізації права, правовій свідомості суспільства.

Важливо відмітити, що правовий режим вебсайтів поки ще недостатньо вивчений. Зокрема, це питання було висвітлено у статті Л. Тарасенко, який зазначав що в переважній більшості випадків на вебсайтах розміщують об'єкти авторського права, бо перева- жно веб-сторінки - вважаються текстовою інформацією [10].

Зауважимо, що в ст. 420 Цивільного кодексу України, де визначено перелік об'єктів права інтелектуальної власності, про вебсайт, як окремий різновид об'єктів права інтелектуальної власності, не згадується. Однак важливо розуміти, що такий перелік не вичерпний. Тобто, у тому разі, якщо вебсайт $є$ результатом інтелектуальної, творчої діяльності, його можна віднести до об'єктів права інтелектуальної власності [11].

Розвиваючи це визначення за структурним підходом, Ю. С. Атаманова наголошує, що досягнення формальної і змістовної єдності вебсайтом забезпечується завдяки трьом основним його складовим, тобто $[1$, с. 7$]$ :

- програмні та апаратні засоби;

- адреса у мережі Інтернет або доменному імені;

- інформаційне наповнення, яке охоплює текстову інформацію, графічну інформацію, аудіовізуальну інформацію.

Однак, проаналізувавши наукову позицію дослідників та законодавця, можно дійти висновку, що в них немає прямої вказівки на приналежність вебсайту до об'єктів права інтелектуальної власності. Але разом із тим до переліку об'єктів авторського права у ст. 8 Закону № 3792-XII включено «інші твори», тому виникає суперечка між науковцями щодо того, чи $\epsilon$ вебсайт окремим об'єктом права інтелектуальної власності або він є просто носієм інформації, яка належить до об'єктів права інтелектуальної власності.

Відзначимо, що, на думку Є.А. Булата, правова природа вебсайту має комплексний характер відповідно до 
його технічної складової частини i графічного та інформаційного оформлення [2, с. 16].

Таким чином, можна зробити висновок про те, що вебсайт є за своєю структурою комплексним, самостійним і окремим об'єктом права інтелектуальної власності в сфері авторського права, так як під час створення потребує використання певних творчих здібностей людини і не має чітко визначеної структури, складається 3 різноманітних об'єктів права інтелектуальної власності, в різних комбінаціях і з особливим їх впорядкуванням, що, породжує унікальність і оригінальність кожного вебсайту, а саме поєднуючи різнорідні за своїм характером об'єкти, вебсайт має ознаки, які не $\epsilon$ сукупністю ознак його складових частин.

На підставі вищезазначеного вважаємо за необхідне здійснити на законодавчому рівні заходи 3 розширення поняття вебсайту та пропонуємо авторське тлумачення: вебсайт - це комплексний об'єкт авторського права, який являє собою сукупність програмного й апаратного забезпечення, веб-дизайну, доменного імені, інформаційного наповнення (контента) i інших об'єктів авторського права та (або) суміжних прав, які пов'язані між собою в різних комбінаціях і з особливим їх впорядкуванням. Також варто доповнити перелік об’єктів авторського права у ст. 8 Закону України «Про авторське право та суміжні права» та переліку об'єктів права інтелектуальної власності у ст. 420 Цивільного кодексу України окремим пунктом «вебсайт» [5, с. 7].

Вивчаючи дану тематику, варто відзначити, що створення сайту також слід розпочати з вибору домену, тобто інтернет-території, що становить собою доменне імя, та його реєстрації. Можна навести приклад за аналогією, коли із зведенням будівельного зеленого паркану, майбутній власник сайту отримує свідоцтво про реєстрацію доменного імені, яке і $\epsilon$ «адресою» майбутнього «будинку» сайту в Інтернеті.

Слід зазначити, що доменне ім'я має доволі складну правову природу. Існує думка, що під доменним ім'ям варто розуміти нематеріальний самостійний актив, що може бути окремим об'єктом обліку та може самостійно брати участь в операціях оренди, відчуження тощо. Але під час створення вебсайта реєстрація доменного імені це один із основних етапів, так як сайт існувати в Інтернеті без доменного імені не може [3, с. 166]. Доменне ім'я може не змінюватися, навіть коли вебсайт переміщується на інший хосткомп'ютер чи сервер. Для прикладу, коли бізнес або домогосподарство переміщують своє місцезнаходження навіть назва родини чи підприємства залишається незмінною у разі зміни адреси [13].

DNS (служба доменних імен) - вважається однією 3 найважливіших технологій, які пов'язані 3 адресою вебсайту. Без DNS доступ до вебсайтів можливий лише через відповідну IPадресу, що включає також ряд номерів (наприклад, 562.123.1.2). Для того, щоб потрапити на ваші улюблені вебсайти в Інтернеті, потрібна довіра до номерів [14].

Варто зазначити, що можуть бути зареєстровані кілька доменних імен, які вказують на один і той самий вебсайт - що є первинним та вторинним доменнем іменем. Первинне доменне ім'я - потрібно, для того, щоб системи 
пошуку індексували та розпізнавали. А вторинні доменні імена можна використати для зручності запам'ятовування та/або реклами [15].

Крім того, для того щоб сайт повноцінно функціонував, слід зареєструвати доменне ім'я, яке ідентифікує сайт в загальному інформативному масиві, та підтримувати роботу комп'ютера, на якому розміщений сайт, а також вирішувати виникаючі проблеми, періодично оновлювати розміщені матеріали, i тощо.

Сьогодні існує два способи ідентифікації вебсайтів - чисельний у вигляді IP-адреси та символьний у вигляді доменного імені. Іноді ці способи називають адресацією.

Доменне ім'я є певним позначенням адреси сервера (комп'ютера), на якому знаходиться потрібна користувачам інформація. Доменне ім'я зазвичай виглядає як, наприклад: www.solnishko.ua. Натомість адреса сервера, тобто комп'ютера, до якого приводить це доменне ім'я (IP-адреса), має, наприклад, такий вигляд: 314. 145.137.365. відповідно такий унікальний номер повинен бути присвоєний кожному комп'ютеру [4, с.173].

Зауважимо, що сам чисельний спосіб адресації даних є зрозумілим комп'ютеру, однак як виявилося, він не $є$ зручним у використанні для користувачів. Тому було застосовано символьну систему адресації даних. За умови запиту одного комп'ютера на пошук інформації, який міститься на сайті 3 певним доменним ім'ям, система DNS перетворить запитуване доменне ім'я на IP-адресу комп'ютера, який має у своєму розпорядженні цю інформацію [3]. Таким чином доменне ім'я можна порівняти 3 ініціалами, тобто ПІБ людини, а IP-адресу - 3 номером їі паспорта.

Треба зауважити, що важливу роль у розумінні функціонування сайтів відіграє його ідентифікації.

Важливим показником при розміщенні певного сайту в Інтернеті вважається Uniform Resource Locator (URL). Тобто існує таке поняття, як URL-адреса, яка складається 3 вказівки шляху до сторінки та доменного імені. Uniform Resource Locator значить показник ресурсів, який є уніфікованим та може використовуватися для вказівки адреси у всесвітній мережі. URL-адреса $\epsilon$ основною мережевою ідентифікацією для різних ресурсів, які підключені до Інтернету (наприклад, звукових файлів , зображень і гіпертекстових сторінок). Для прикладу зазначимо, що, URL-адреса домашньої сторінки Університету Індіани - це http://www.indiana.eu/. URL може працювати лише з цифрами, буквами латинського алфавіту, та деякими символами [16].

Зауважимо і про особливості безпеки використання URL. Так, в компанії Google було переглянуто безпеку використання URL у зв'язку з підвищенням мобільного пошукового трафіку. Насамперед через те, що певні сучасні смартфони користуються іншою системою ідентифікації сайтів. Таким чином за умови слабкості даних технологій, хакери зможуть вкрасти інформацію, яка $\epsilon$ важливою для користувача. Також було відмічено, що звичайному користувачеві доволі важко читати URL-адреси, саме тому важко i розпізнавати, яка інформація є достовірною, а яка - ні. У зв'язку з чим компанія Google заявила, що їхніми спеціалістами розробляється нова технологія задля ідентифікації сайтів, яка 
прийде на заміну URL-адрес, важливою метою якої $є$ понад усе безпека функціонування вебсайтів [17].

Окрім важливості ідентифікації сайтів, значну роль, з юридичної точки зору, відіграє механізм облікового відображення вебсайтів.

О. С. Яворська зазначає, що згідно Закону України «Про авторське право і суміжні права» поняття «обліковий запис», що представляе собою «формалізований згідно зі стандартами мережі Інтернет запис на комп'ютерному обладнанні (комп'ютерах, серверах), підключеному до мережі Інтернет, що ідентифікує користувача (наприклад, власника веб-сайту) на такому обладнанні, включає в себе дані про доступ до частини каталогів і програмного забезпечення комп'ютерного обладнання, а також визначає права такого доступу, що надають можливість володільцю облікового запису додавати, видаляти, змінювати електронну (цифрову) інформацію і дані вебсайту, надавати доступ до веб-сайту або його частин, окремих даних іншим особам, припиняти функціонування такого веб-сайту або його частини в межах облікового запису» [9, с.33].

Щодо облікового запису, то слід зауважити, що завдяки йому можна ідентифікувати користувача мережі Інтернет, зокрема власника вебсайту, i користувача соціальних мереж або інших веб-ресурсів (обліковий запис в Google) [18].

Зауважимо, що вебсайт складається 3 веб-сторінок. Реєстрант, тобто власник вебсайту, не завжди є власником веб-сторінки. Крім того, власник вебсайту не $\epsilon$ власником веб-сторінки, якщо останній володіє обліковим записом, що дає йому можливість самостійно, незалежно від власника вебсайту, розміщувати інформацію на веб-сторінці та керувати нею (ст. 1 Закону України «Про авторське право i суміжні права») [12].

Такий підхід вважається доволі виправданим, так як дуже часто користувачі вебресурсів наділені технічною можливістю наповнювати контент самостійно [19]. Для прикладу це може бути обліковий запис на веб-порталах, у різних соціальних мережах, коли користувач сам формує інформаційну складову свого облікового запису, викладаючи в публічний доступ ту інформацію, яку вважає за необхідне. Окрім того, норма $\epsilon$ важливою $з$ огляду на потенційний суб'єктний склад спору, який може виникнути за умови порушення цією особою авторських або суміжних прав. У такому випадку саме власник веб-сторінки повинен бути відповідачем у даній категорії справ. Відповідаючи на питання, чи повинен власник вебсайту нести відповідальність за порушення авторських прав, яке відбувається на його вебсайті, варто провести порівняння зі суб' єктним складом розгляду справ, які пов'язані 3 порушенням авторських прав у друкованих 3МI або різноманітних виданнях. Також слід зауважити, що на рівні $з$ автором публікації, відповідачем вважається також і видавець. Так, 3 Постанови Пленуму ВСУ «Про застосування судами норм законодавства у справах про захист авторського права і суміжних прав» [20] слід розуміти, що у справі про захист авторського права належним відповідачем слід вважати особу, якою було порушено майнові або особисті немайнові права суб' єктів авторського права. Цей аспект варто розглядати як важливий постулат 3 точки розу права інтелектуальної власності. Також у цій 
Постанові чітко визначено, що у разі вирішення відповідних певних спорів, суд має встановити, чи перебуває вебсайт, а також розміщена на ньому інформація, в розпорядженні особи, котрій пред'явлено позовні вимоги та чим підтверджується факт порушення особою авторського права. Такі дані щодо власника вебсайту мають бути витребувані згідно чинного процесуального законодавства держави. Зазначена інформація повинна бути витребувана через адміністраторів системи реєстрації чи обліку доменних назв і адреси українського сегмента мережі Інтернет (п. 31 Постанови) [20].

Також варто наголосити про те, що подібне роз'яснення зазначено і в постанові Пленуму Вищого господарського суду України «Про деякі питання практики вирішення спорів, пов'язаних із захистом прав інтелектуальної власності», де відзначено, що власників сайтів, на яких розміщуються твори без надання дозволів відповідно до закону, слід визнати порушниками авторського права [21]. Однак вважається, що впевненість такої позиції слід вважати досить суперечливою, адже це правило не завжди має застосовуватися на практиці, так як через глобальний розвиток відносин в сфері інтернету, можуть бути спричинені появи різних видів вебсайтів, що за своєю технічною сутністю надаватимуть можливість користувачам самим викладати на них об'єкти авторських або суміжних прав тощо.

Для прикладу можна розглянути такі популярні соціальні мережі, як Instagram чи Facebook, а також сервіси компанії Google (наприклад YouTube) та інші, в межах яких користувачі інтернету можуть поширювати власний контент, наприклад фото чи відео, що вважаться інформацією, яка містить певні об'єкти права інтелектуальної власності. Таким чином дані вебсайти визначають, що користувачі $\epsilon$ відповідальними за порушення прав інтелектуальної власності, але разом із тим пропонують механізм припинення такого порушення [22]. Для прикладу варто зауважити, що YouTube має можливість надсилати сповіщення щодо порушення авторських прав, яке розглядається адміністрацією вебсайту і у разі існування певних підстав встановлює заходи щодо видалення відповідного потенційного неправомірного контенту. Однак такі популярні сайти як YouTube i Facebook зареєстровані не в Україні, і, відповідно, не підпадають під дію вітчизняного законодавства та роз'яснень вищих судових інстанцій [10, с.135]. Також вкрай важливим і досі нерозкритим є питання щодо права інтелектуальної власності на матеріали, розміщені науковцями [23].

Висновки. Отже, на підставі проведеного дослідження, можна зробити наступні висновки. Вебсайт на законодавчому рівні вважається об'єктом права інтелектуальної власності, оскільки містить в собі сукупність апаратного й програмного забезпечення, доменного імені, веб-дизайну, інформаційного наповнення (контенту) та інших об'єктів авторського права і (або) суміжних прав. Правова природа вебсайту має комплексний характер 3 огляду на його технічну складову частину та графічне й інформаційне оформлення. Сьогодні існує два способи ідентифікації вебсайтів - символьний у вигляді доменного імені й чисельний. Встановлено, що завдяки обліковому запису можна ідентифікувати користувача в мережі Інтернет. 
Вважаємо, що в майбутньому варто розглядати це питання 3 точки зору використання методологічних підходів та методів оцінки інтелектуальної власності для визначення вартості вебсайту, розроблення методики оцін- ки вартості вебсайту, як складного об'єкта інтелектуальної власності, розроблення рекомендацій щодо захисту прав на вебсайт на законодавчому рівHi.

\section{Список використаної літератури}

1. Атаманова Ю. С. Захист прав інтелектуальної власності у мережі Інтернет: світовий досвід та вітчизняні перспективи. Право та інноващзї, 2014. № 3. С. 7. 2. Булат Є. А. До питання правової охорони веб-сайту. Науковий вісник Міжнародного гуманітарного університету, 2015. № 13 (2). С. 16-17.

3. Губіна I. Веб-сайт: райський острів в Інтернет-океані. Нематеріальні активи: правові та облікові аспекти, 2009. № 6. С. 166-172.

4. Деркач Т. Доменне ім'я: проблеми визнання нематеріальним активом. Нематеріальні активи: правові та облікові аспекти, 2009. № 6 С. 173-179.

5. Михайліна Т., Борівська В. Правовий режим веб-сайту та його складників як об'єктів інтелектуальної власності. Підприємництвво, господарство $i$ право, 2021. № 4. C. 5-9.

6. Jackson L. D. Introduction To The Internet And Web Page Design. Southern Utah University. URL: https://www.suu.edu/hss/comm/masters/capstone/project/ ljackson.pdf?fbclid=IwAR3IIXVi_jlrFKeI5OxhAF_Ct5ifT0y0__EFfRTIUInt6qqU ZVT_Q14rc

7. What Does Website Mean? Techopedia. URL: https://www.techopedia.com/definition/5411/website?fbclid=IwAR2Cq2kVW_c2Vv nF_MSS1I57SY4vJ6LHHgS4XFga6vV2zbOv_5_LTMMMjA

8. Про державну підтримку кінематографії в Україні: Закон України від 23.03.2017 № 1977-VIII URL: https://zakon.rada.gov.ua/laws/show/1977-19\#n396 (дата звернення: 28.09.2021)

9. Яворська О. С. ІТ право. Львів : Видавництво «Левада», 2017. 470 с.

10. Тарасенко Л. Правовий режим веб-сторінки. Вісник Львівського університету. Серія юридична, 2017. № 65. С. 134-144.

11. Цивільний кодекс України: Кодекс України: Закон, Кодекс від 16.01.2003 № 435-IV URL: https://zakon.rada.gov.ua/laws/show/435-15\#Text (дата звернення: 28.09.2021) 
12. Про авторське право і суміжні права: Закон України від 23.12.1993 № 3792XII URL: https://zakon.rada.gov.ua/laws/show/3792-12\#Text (дата звернення: 28.09.2021)

13. Harpham M. Suggested websites. DOI:10.4324/9781003129691-17

14. What is a URL? University Information Technology Services. Knowledge base. URL: https://kb.iu.edu/d/adnz?fbclid=IwAR1dy3u-2cKThePEk4EgAgdTuM_KZxpP4amPDEXqIx2f8qe9da4GPJGWwc (дата звернення: 28.09.2021)

15. What Makes A Good Website Address? Onlineinnovations. URL: https://www.onlineinnovations.com/article/what-makes-a-good-websiteaddress?fbclid=IwAR1iIrBq76Uhlcy3O7zm1puQB_2fbT46KC3BMfnc4epuGtpYMmL3MGrhZ8 (дата звернення: 28.09.2021)

16. Kaleth J. Definition of Website Address. ItStillWorks. URL: https://itstillworks.com/definition-website-address-11802.html (дата звернення: 28.09.2021)

17. Новий спосіб ідентифікації сайтів від Google. PROject SEO. URL: https://project-seo.net/uk/blog-uk/novyj-sposib-identifikaciji-sajtov-vid-google/ (дата звернення: 28.09.2021)

18. Aziz N. S. A Review of Website Measurement for Website Usability Evaluation. Journal of Physics Conference Series. DOI:10.4324/978100312969117DOI:10.1088/1742-6596/1874/1/012045

19. Meredith D. Build a Quality Website. Explaining Research. URL: DOI:10.1093/oso/9780197571316.003.0008 (дата звернення: 28.09.2021)

20. Про застосування судами норм законодавства у справах про захист авторського права i суміжних прав: Постанова Верховного суду України від 04.06.2010 № 5. URL: https://zakon.rada.gov.ua/laws/show/v000570010\#Text (дата звернення: 28.09.2021)

21. Про деякі питання практики вирішення спорів, пов'язаних із захистом прав інтелектуальної власності: Вищий господарський суд: Постанова від 17.10.2012 № 12. URL: https://zakon.rada.gov.ua/laws/show/v0012600-12\#Text (дата звернення: 28.09.2021)

22. Beginner's Guide to Domain Names. ICANN URL: https://www.icann.org/en/system/files/files/domain-names-beginners-guide-06dec10- 
en.pdf?fbclid=IwAR1CaCKdJIFegWAmJUMztQ227oxVpNsfyat1TS6Dty1k7SR18n P8Pu5Jp9o (дата звернення: 28.09.2021)

23. Kuchner M.J. What makes a: Good website for scientists? Researchgate. URL: https://www.researchgate.net/publication/297708286_What_makes_a_Good_website _for_scientists (дата звернення: 28.09.2021) 